УДК 791.43:32.019.52(497.1+497.2+438)"193"

316.75:791.4(4)"193"

Bojan SIMIĆ, Ph. D.

\title{
FILM IN THE SERVICE OF STATE PROPAGANDA DURING THE 1930s, CASES OF POLAND, YUGOSLAVIA AND BULGARIA*
}

\begin{abstract}
Based on primary sources and relevant literature the development of film and its role in the state propaganda of Poland, Yugoslavia and Bulgaria during the 1930s will be analyzed in this study.
\end{abstract}

Key words: Film, Propaganda, Poland, Yugoslavia, Bulgaria

Film was probably the most powerful propaganda tool between two world wars. The film industry was more advanced in America than in Europe during the interwar period. The USA had 17,000 cinemas in 1937, the Soviet Union had 6,337 while the situation in the leading European countries was: Germany 5,395, UK 5,000, France 3,700 and Italy 3,600 cinemas. ${ }^{1}$ The widespread use of film as a propaganda tool began in Bolshevic Soviet Union ${ }^{2}$ and it quickly spread all over the world. Propagandistic film was especially popular in Fascist Italy and Nazi Germany. ${ }^{3}$ The three countries reviewed (Poland, Yugoslavia and Bulgaria) also used film and cinema in state propaganda purposes but

* Рад је настао у оквиру пројекта Традиција и трансформација. Историјско наслеђе и национални идентитети у Србији у 20 веку, (№ 47019), који финансира Министарство просвете и науке Републике Србије.

1 Maly Rocznik Statysticzny [A Small Statistical Yearbook], (Warsaw, 1938), p. 336. Data was taken from the Bureau of Foreign and Domestic Commerce, (Washington, 1938).

2 From various literature on the topic see: D. Gillespie, Early Soviet Cinema, Innovation, Ideology and Propaganda, (London, 2005); P. Kenez, The Birth of the Propaganda State (Soviet media and mass mobilization), (Cambridge, 1986).

3 From various literature see: D. Welch, Propaganda and the German Cinema 19331945, (New York, 1983); N. Reevs, The Power of Film Propaganda, (New York, 2003); S. Ricci, Italian Film and Society, 1922-1943, (Los Angeles, 2008). 
they were was limited by the existing technical advancement and the prevailing economic climate.

General situation in the film industry in the three countries

Comparing the number of citizens and number of cinemas with other European nations, Poland was third from the bottom, ahead of only Yugoslavia and Albania. In 1939, the total number of cinemas was 789 , only 300 of which operated every day. The statistical data of that year stated that $98 \%$ of the films in Polish cinemas were imported (62\% from the USA, $13.4 \%$ from Germany, $10.8 \%$ from France). ${ }^{4}$ On average, each Polish citizen only went to the cinema 1.5 times in 1938 while citizens of some towns attended the cinema more frequently than the national average, e.g. each citizen in Lvov went to the cinema 13 times on average in 1938 and this figure was 12 for both Warsaw and Poznan. ${ }^{5}$

Films from the United States were the most popular imported films into Poland during the 1930s with Germany in second place and France way back in third. The share of US films imported into Poland was always around $60 \%$ but in 1935 , this figure rose to $77 \% .^{6}$ The number of Polish films varied during the years as illustrated in the following table:

Polish films in the 1930 s

\begin{tabular}{|c|c|c|c|}
\hline Year & Polish films & $\begin{array}{c}\text { Polish films } \\
\text { per thousand } \\
\text { meters long) }\end{array}$ & $\begin{array}{c}\text { Total number of } \\
\text { Polish films \% }\end{array}$ \\
\hline 1931 & 198 & 100 & 10.5 \\
\hline 1932 & 146 & 92 & 12.3 \\
\hline 1933 & 157 & 83 & 10.7 \\
\hline 1934 & 142 & 68 & 11.0 \\
\hline 1935 & 113 & 64 & 9.7 \\
\hline 1936 & 124 & 82 & 13.4 \\
\hline 1937 & 123 & 94 & 13.4 \\
\hline
\end{tabular}

Source: CAW, Gab. MSWojsk, I.300.1.538

4 Polska Niepodlegla, (Warsaw, 2008), p.469.

5 Ibid.

6 Centralne Archiwum Wojskowe (Central Military Archive, CAW), Gab. MSWojsk (Cabinet of Minister of War), I.300.1.538. 
This data illustrated that the number of films was decreasing, but that the share of Polish films released in Poland grew slightly in percentage terms from 1931-1937, but government officials were not impressed with these figures, even the increase of more than $30 \%$ from $1935-1937$ as well the increase of $78 \%$ in the production of full length feature films. In total, out of the 24 of these types of films produced in 1937, 10 were comedies, 11 were dramas, two were melodramas and one was a review with the total costs of those films being $5,750,000$ zlotys. $^{7}$

It was clear that a figure of around $10 \%$ Polish films being released in Poland was not satisfactory both for state propaganda and for the people that worked in the culture industry and there were lively discussions over the years about the future development of the film industry in Poland. Something had to be done.

A new organization was formed called the Movie Section (Sekcja Filmova), which consisted of members of important ministries and they met several times to discuss the way forward. These members included representatives of the: Ministry of Foreign Affairs, Interior Ministry, Ministry of Industry and Commerce, Ministry of Religious Affairs and Public Education, members of Military Institute of Research and Education (WINO) ${ }^{8}$, Polish Telegraph Agency (PAT) ${ }^{9}$ and government party Camp of National Unity (OZN) ${ }^{10}$ and on some occasions, they had invited some guest participants to their meetings like script writers and legal experts. ${ }^{11}$

During those meetings, plans and actual problems were discussed and one of the key problems that emerged in these meetings was a lack of financial recourses for the development of domestic cinematography. This was mainly due to a low level of trade and capital which was being invested in film production. A representative of the PAT, Tadeusz Katelbach underlined that the Ministry of Industry and

CAW, Gab. MSWojsk, I.300.1.538.

8 More about WINO see in: L. Wyszczelski, Oswiata, propaganda, kultura Wojsku Polskim w latach 1918-1945 [Education, Propaganda, Culture in Polish Army 19181945], (Warsaw, 2004).

9 More about PAT see in: W. Grabowski, Polska Agencja Telegraficzna 1918-1991 [Polish Telegraph Agency 1918-1991], (Warsaw, 2005).

10 About OZN see in: Wynot, E. D, Polish Politics in Transition, The Camp of National Unity and the Struggle for Power, 1935-1939, (Athens, 1974).

11 CAW, Gab. MSWojsk. I.300.1.531. At the meeting on 25 th February 1938, Antoni Cwojdzinski, a script writer and Andrzej Ruszkowski, a legal expert in the film industry were also invited. 
Commerce allocated a "symbolic" figure of 100,000 zlotys in its budget for the film industry during the period of 1936-1937. This figure was very low compared with $1,000,000$ zlotys in $1931 . .^{12}$ These meetings also underlined the importance of short films for propaganda purposes in Poland and several suggestions were made to increase the financing of the Polish film industry.

The film industry in the Kingdom of Yugoslavia had always served the propaganda purposes of the ruling circles, especially the royal family of Karadjordjevic. When one considered the lack of education and general knowledge amongst the majority of citizens in the Kingdom of Yugoslavia at the time, it is safe to conclude that this "technological miracle" had an important political influence on these citizens.

The number of cinemas and seats in the Kingdome of Yugoslavia (1935-1938)*

\begin{tabular}{|c|c|c|c|c|}
\hline Year & $\begin{array}{c}\text { Sound } \\
\text { cinema }\end{array}$ & $\begin{array}{c}\text { Silent } \\
\text { cinema }\end{array}$ & $\begin{array}{c}\text { Total number of } \\
\text { cinema }\end{array}$ & $\begin{array}{c}\text { Total number of } \\
\text { seats }\end{array}$ \\
\hline 1935 & 262 & 33 & 295 & 92,905 \\
\hline 1936 & 301 & 17 & 318 & 106,014 \\
\hline 1937 & 330 & 13 & 343 & 113,971 \\
\hline 1938 & 357 & 13 & 370 & 121,120 \\
\hline
\end{tabular}

* This number included travelling "silent" cinemas: for 1935 at 22, 1936 at 31, 1937 at 40 and cinemas 1938 at 14. Source: Statistical Yearbooks of the Kingdome of Yugoslavia (1934-1939)

In the Kingdom of Yugoslavia, the existing cinemas had different programs. For example, 108 cinemas showed films every day while 110 cinemas only showed films twice a week. Out of the biggest cities, Belgrade had 18 cinemas and Zagreb $16^{13}$ and American films were dominant in those cinemas. During 1935, 678 films were imported and from this list, 436 came from the United States (64\%), 144 from Germany (21\%), 30 from Austria (4\%) and 27 from France (3\%). ${ }^{14}$

12 CAW, Gab. MSWojsk. I.300.1.538. The specific meeting was held on $13^{\text {th }}$ January 1938.

13 All data from 1938. Statistički godišnjak [Statictical Yearbooks of the Kingdome of Yugoslavia for 1938-1939], p. 396.

14 Centralen Darzaven Istoricheski Arhiv (Central State Historical Archive), Sofia, CDA, 177k-3-927/1. Izveštaj Državne filmske centrale o prometu filmova i stanju kinematografa u Kraljevini Jugoslaviji 1935. godine [The Report of State Film Cen- 
Using the Section for Film and Tourism, the Central Press Bureau that was the unofficial Ministry for Propaganda ${ }^{15}$, showed propaganda films that were primarily political. The main task of this section was to record all important political events, make films about them and then distribute those films to a wider audience. According to its data in 1936, the CPB produced 7,065 meters of film and all the other producers only $6,675^{16}$, so it is safe to conclude that the Central Bureau was the biggest producer of films in the Kingdom of Yugoslavia. In addition to the procurement of modern equipment for the Section for Film and Tourism, the CPB also established good relations with foreign producers, especially those from Germany. ${ }^{17}$ Apart from making and distributing films, the Section for Film and Tourism dealt with the censorship of films and other products that were to be shown in the country as well as with the censorship of foreign films that were imported, together with the official CPB's section for the implementation of the press law. These joint activities meant that the CPB had almost complete control over the development of the film industry in Yugoslavia.

According to the chief of the Cultural Section of the Bulgarian propaganda institution Renewal, ${ }^{18}$ cinema was unknown to around $80 \%$ of the population in Bulgaria, ${ }^{19}$ but statistical data shows otherwise. The number of cinemas in Bulgaria was indeed the lowest of the three countries reviewed according to statistics that number during the following years was:

ter on the distribution of films and the state of cinemas in Kingdome of Yugoslavia for 1935].

15 More about CPB see in: Б. Симић, Пропаганда Милана Стојадиновића (Milan Stojadinovic's Propaganda), Belgrade, 2007, pp. 79-103.

16 Central Press-Bureau of the Council of Ministers, Izveštaj o radu za 1936. godinu [Annual Report for 1936], p. 66.

17 Leni Rifenstal visited Belgrade while filming Olympia what CPB used for improving relations with the "leader of German film".

18 More about Renewal see in: К. Чуканов, 'Дирекцията на Обновата (1934-1935). Към началото на институционализацията на Българската национална пропаганда' (Towards Institutionalization of Bulgarian National Propaganda), Минало, 3/2012, pp. 87-96.

19 CDA, 232k-1-20/22. Undated document, probably from February-March 1935. 
Number of Cinemas in Bulgaria During the 1930's

\begin{tabular}{|c|c|}
\hline Year & Number of Cinemas \\
\hline 1933 & 114 \\
\hline 1934 & 121 \\
\hline 1935 & 114 \\
\hline 1936 & 116 \\
\hline 1937 & 120 \\
\hline 1938 & 142 \\
\hline 1939 & 155 \\
\hline
\end{tabular}

Source: Statisticheski godishnaci na Balgarskoto Tsarstvo 1937-1940 [Annual Statistical Surveys of the Bulgarian Kingdome 1937-1939], (Sofia, 1937-1940).

As seen, the number of cinemas constantly grew, except in 1935 due to the economic crisis and this year was also critical due to the difficult economic climate in both Poland and Yugoslavia. Sofia had the most cinemas in 1936, it had 32 of the 116 existing cinemas.

The most complete data, in the existing statistics, can be found for the year 1939. Of the 155 cinemas in Bulgaria, only 32 were in the villages and 123 in the cities. Judging by the country they were produced in the films showed in Bulgaria were more balanced than in Poland and Yugoslavia. Of 10,524 films showed, only 3,775 showed films in English (35.9\%). Of the others film showings, 2,833 were French speaking (26.9\%), 2,622 were in German (24.9\%) and interestingly, 608 films came from the Soviet Union (5.8\%). As one could see, films from the first communist country in the world were not imported or mentioned in the other two states under review. That could be due to the historical connections between Bulgaria and Russia and the fact that the Russian language and culture were closer to the ordinary Bulgarian citizen. On the other hand, only 117 film showings were Bulgarian films (around 1\%). ${ }^{20}$

20 Statisticheksi godishnak na Balgarskoto Tsarstvo 1939 [Annual Statistical Survey on the Bulgarian Kingdome 1937], (Sofia, 1940), p. 736. 
Film Legislation in Poland, Yugoslavia and Bulgaria During the 1930 s

It is very important to understand the legislation that regulated the movie industry and how the three states understood and used this powerful propaganda weapon. The most important document regarding legislation referring to the cinema in Poland during the 1930 s was the law passed in March 1934. It regulated various matters such as office rent, records and laboratories, import of films, promotion of domestic production, position of cinema, theatre and their technical personnel and censorship.

The examination of films and advertisements was supposed to have been carried out by committees, whose membership, methods of appointment and dismissal, duties and powers were supposed to be specified by a regulation issued by the Minister of Internal Affairs and the Minister of Religious Affairs and Public Education (Art.18). One later article, specified various reasons why some films should be banned: "The authority can refuse permission to release the movie if the test shows that the public showing would either jeopardize the vital interests of the Republic, security, tranquility and public order, damage the reputation of the Republic, or its relations abroad, damage the national honor or insult religious feelings, invoke a call to war, invoke savagery which affects the viewer or which has a demoralizing affect on them". ${ }^{21}$

The film industries of these countries were also under the censorship of the state apparatus and when it came to making films in Yugoslavia, state intervention began in 1928. That year the financial legislation proscribed that not one movie could be shown until it had been checked by the censors from the Ministry of Education".22 During the 1930s, the film industry was governed by the State Film Center (Државна филмска централа) and a special censors' committee, which consisted of twelve members and their deputies. The members of this committee were three representatives from the Ministry of Education, one representative from the Ministry of Army and Navy, two representatives of the Ministry of Social Welfare and Public Health

21 Ustawa o filmach i ich wyświetlaniu [The Law About Films and Their Display], Dzienik Ustaw. Poz. 323, Nr. 36, p. 586.

22 Љ. Димић, Културна политика Краљевине Југославије 1918-1941, [Cultural Policy of Kingdome of Yugoslavia], III, (Belgrade, 1997), р. 332. 
(one member was a representative of the national women's educational organizations), two representatives of the Ministry of Interior Affairs, one representative of the Ministry of Trade and one from the Central Press-Bureau. ${ }^{23}$ The law set the tasks of this organization as follows: tion of films;

a) to arange and oversee the import, production and distribu-

b) to develop the domestic film industry;

c) to help educational and useful film propaganda. ${ }^{24}$

The valid law in this area in Bulgaria during the 1930s was legalized in April 1930. ${ }^{25}$ The first article underlined that cinematography was under the supreme control of the Ministry of People's Education. Members of the censor's committee were as follows: The chief of Department of cultural institutions and funds in the Ministry of People's Education, the prosecutor from the Sofia district or his deputy, one representative of Interior Ministry, one representative of Ministry for Health, one representative from the Educational Committee and two special members delegated by the Minister of People's Education (article 12). Representatives of other Ministries or institutions were only invited if the nature of the film requested their presence.

\section{Censorship and Film Production}

At this point, it is important to mention some data about censorship, which was present and established by the law in these countries. Accordingly, the statistical data in Poland is as follows:

Number of censored film in Poland 1934-1937

\begin{tabular}{|c|c|c|}
\hline Year & Censored films & Cleared films \\
\hline 1934 & 780 & 769 \\
\hline 1935 & 714 & 699 \\
\hline 1936 & 652 & 638 \\
\hline 1937 & 619 & 605 \\
\hline
\end{tabular}

Source: Maly Rocznik Statysticzny [A Small Statistical Yearbook], (Warsaw, 1938), p. 336.

23 Arhiv Jugoslavije (Archive of Yugoslavia, AY), Ministry for Education (66), folder no. 383, The Book of Regulations of the Censorship of Films of 22 February 1932.

24 The Law on the Distribution of Films from $5^{\text {th }}$ December 1931 with changes and appendixes according to the article 57/7 of the Financial Law from 1933/34.

25 The "Law for Cinematography" was published on $29^{\text {th }}$ April in the State's Journal. 
As one can see, most of the films that came to the censors' attention were cleared for broadcasting. This was due to the fact that most of the films were already made with the standards that would have been considered "acceptable".

The State Film Center in Yugoslavia was a very busy institution. Only in 1935, they sent 779 films to the censors and of these, 100 were domestic and 678 foreign. Only 14 films were banned, all of them foreign. ${ }^{26}$

One of the most important institutions for film propaganda of the Second Polish Republic was the Film Department of the PAT (Wydział Filmowy PAT). This department was formed in 1929 for the production of silent short films. After acquiring modernized equipment in 1933, they started with the regular chronicles PAT's Weekly Film Magazine (Tygodnik Filmowy PAT). Besides political films, other films included other genres like the musical, cultural, artistic etc...

Short films had the greatest propaganda significance in the Polish film industry and these consisted of a weekly newsreel produced by PAT. That production started in 1927 and until the outbreak of Second World War, around 600 of them were produced and broadcast. Those films were about 10 minutes long and only consisted of current news. It is crucial to mention that the PAT's newsreels were broadcast in every cinema before the regular film were shown and in this instance, the propaganda impact was very strong and some serious results could have been achieved. Even the people who did not share the government's point of view could have been consciously or subconsciously influenced by those journals.

There were also some special films dedicated to some specific topics. Sometimes, these were cultural and educational but on some occasions, they were pure political propaganda. In 1936, such films were: Long Live the Army (Niech Zyje Armia), Journey of General Edward Rydz Smigly to France (Podróż Gen.Edwarda Smigłego Rydza do Francji) and Long Live Polish Marshal Edward Rydz Smigly (Niech Zyje Marszałek Polski Edward Smigły Rydz). ${ }^{27}$ The first film about

26 CDA, 177k-3-927/1. Izveštaj Državne filmske centrale o prometu filmova i stanju kinematografa u Kraljevini Jugoslaviji 1935. godine [The Report from the State Film Center about distribution of films and the state of cinemas in the Kingdome of Yugoslavia for 1935].

27 Archiwum Akt Nowych (Archive of Modern Documents, AAN), Ministry of Foreign Affairs 8-21II. 
the second Polish marshal was 200 meters and the other was 180 meters long. ${ }^{28}$ In the same year, personnel of the PAT's film section ("Wydział Filmowy", founded in 1928) consisted of only 17 editors, eight technicians and four janitors and messengers. ${ }^{29}$

With the establishment of the Central Bureau of Film (Centralne Biuro Filmowe, founded in 1928) at the Interior Ministry the ruling circles in Poland showed more interest in film. However the films in the propaganda sector were very small and ineffective. Only in 1937, the newly formed Polish Film Company (Polska Spółka Filmowa) made a patriotic and propaganda film Hearts Aflame (Płomienne serca) directed by Romuald Gantkowski. ${ }^{30}$ The film was well received by the authorities, received awards at the Film Fair in Lvov and prizes from the War and Interior Ministries. Much less successful was the label OrionFilm whose film The Commander (Komendant) directed by Henryk Bigoszta $^{31}$ had not been approved by the censors for broadcast. ${ }^{32}$

As one could see earlier, twenty films had already been made by the CPB in Yugoslavia during 1936 and all of these were broadcast in cinemas all over the country. Amongst the most interesting film titles, one could choose either:

- Travel of the Prime Minister through Montenegro (broadcast for 247 days with a total of 741 broadcasts in 55 cinemas in 46 different places);

- Meeting of Little Antanta in Bled (broadcast for 252 days with a total of 765 broadcasts in 70 cinemas in 54 different places);

- The Opening of the Railroad Veles - Bitola (broadcast for 137 days with a total of 411 broadcasts in 28 cinemas in 26 different places);

- Celebrations in Zenica (broadcast for 83 days with a total of 249 broadcasts in 18 cinemas in 17 different places)... ${ }^{33}$

28 CAW, General Inspector of the Armed Forces - GISZ 302.4.1634.

29 CAW, General Inspector of the Armed Forces - GISZ 302.4.1634.

30 Romald W.Gantkowski (Poznan, 14. VII 1908 - Hollywood, USA, 17. III 1989) was Polish director, scriptwriter and actor. His most famous films in the Interwar period were: Girl Looking for Love (Dziewczyna szuka milosci, 1938) and The Genius of the Scene (Geniusz szeny, 1939).

31 Henryk Bigoszta (Kalvaria, 5. V 1895 - Cracow, 20. III 1971) was Polish film director. His well-known films were: Kalisz (1918), A Cry in the Night (Krzyk w nocy, 1922) and Kizia-mizia (1922).

32 Brzoza, Sowa, Historia Polski, p. 432.

33 Central Press-Bureau of the Council of Ministers, Izveštaj o radu za 1936. godinu [Report of annual work for 1936], p. 64. 
The most interesting film from the propagandistic point of view in Yugoslavia was made in late 1938. The novelty was introduced during the government of Milan Stojadinovic (1935-1939) and a special Party propaganda film On the Path of Restoration - Yugoslavia Yesterday, Today and Tomorrow (Путем препорода - Југославија јуче, данас, сутра) was made ${ }^{34}$ This film was specially prepared for the pre-election campaign of December 1938.

The movie was produced in co-operation with experts from the NSDAP and it was edited in Germany with the assistance of personnel from the government party JRZ. This group was led by Vojin Djordjević, an official of the JRZ and the first secretary of the State Film Center. His presence left a lasting mark because he was the presenter in the film, but this cooperation was not without difficulty. In his report, Djordjevic said that Baron Von Wolzogen did things his way and often insisted on using some effects at the expense of the context. ${ }^{35}$ The German side also promised the gift of one million film posters, but there was no evidence that this promise was kept. ${ }^{36}$ The film arrived late, more than month after the election campaign had began mainly due to the fact that the election campaign had already started when the idea to make the film was first discussed. 32 copies of the film arrived in Yugoslavia and during the final two weeks before the elections, the government propaganda focused its efforts on broadcasting the film in as many locations as possible. Purposefully, some cities in Croatia were avoided as no result was expected there and according to some reports, the greatest impact of this propaganda was felt in Belgrade. ${ }^{37}$

The Director of Renewal Popzlatev, in his report in May 1935, in the final days of this propaganda institution, said that the propagandistic role of cinema did not develop due to some internal problems within the government. ${ }^{38}$ One of the reasons for that statement was the fact that control over the cinema remained in the hands of the Education Ministry and never passed to the Renewal. The Ministry strongly opposed to idea that control of the cinema should be entrusted to Popzlatev's institution.

34 For the transcript of the movie see Симић, Пропаганда..., pp. 319-324.

35 AY, 37-12-388/390, The Report of Vojin Djordjevic sent to Gradimir Kozomaric, chief of Film Section of JRZ.

36 AY, 37-12-383, The Letter of Gradimir Kozomaric sent to Milan Stojadinovic from $3^{\text {rd }}$ November 1938.

37 AY, 37-12-392.

38 CDA, 284k-3-42/35-36. 
In Bulgaria, as in Yugoslavia, there were films dedicated to the royal dynasty. Those films were propagandistic by nature and were intended for all social groups. Naturally these films did not have any problems with the censors. The most famous Bulgarian films with the national propaganda topics in the 1930s were: Revolt of the Slaves (Бунтьт на робите, 1933) Tracks of the Balkan (Песента на Балкана, 1934), In front of the Fatherland We Should Forget Hate (Пред отечеството да забравим омразата си, 1935), Enemies (Врагове, 1938), Duke Strahil (Страхил войвода, 1938). During the 1940s, several new films were released with the help of the foundation Bulgarian Deed (Българско дело). The most well-known films with the strongest national propaganda messages were For the Motherland ( $3 a$ родината) and They Won (Те победиха). ${ }^{39}$

The media played a key role in creating, developing and spreading the government propaganda in Poland, Yugoslavia and Bulgaria during the 1930s. The press was the most disperse and the most used tool, but the use of radio and film increased rapidly, especially in the final years before World War Two. The film industry was the easiest to control for the governments of the three countries because censorship was legalized and constantly present during the period under review. The government committees examined every film, domestic or foreign and only those considered acceptable were broadcast in the cinemas. Domestic production of films in Poland, Yugoslavia and Bulgaria was poor in comparison to imported films and the companies owned by the government, or government institutions, made several short propaganda films and numerous newsreels in an attempt to influence public opinion in its favor. Nevertheless, despite its relative lack of numbers, the impact of film could not be underestimated because it offered more than the press and radio because it combined the effects of picture and sound.

39 A. Grozev, Nachaloto. Iz istoriyata na balgarskoto kino 1896-1956 [The Beginning. From the History of Bulgarian Cinema 1895-1956], (Sofia, 1985), pp. 77-84 and pp. $165-168$. 


\title{
Резиме
}

\author{
Др Бојан Симић
}

\section{Филм у служби државне пропаганде 30-их година. Примери Пољске, Југославије и Бугарске}

Кључне речи: филм, пропаганда, Пољска, Југославија, Бугарска

Између два светска рата филм је био једно од најмоћнијих средстава државне пропаганде у свету али и у источној и југоисточној Европи. Почетком тридесетих година прошлог века филмска индустрија у Пољској, Југославији и Бугарској била је тек у раној фази свог развитка и ове државе су биле на самом дну европске лествице, имајући у виду број становника и број постојећих биоскопа. Убедљиво највећи број филмова на репертоару биоскопа био је страног порекла, углавном америчких, док је домаћа продукција чинила веома мали део програма. Сви филмови, домаћи и страни, морали су проћи цензуру, која је била и законски предвиђена и регулисана. Наведена чињеница омогућавала је владајућим круговима да имају скоро потпуну контролу над емитованим садржајем. И поред економских ограничења, филмски радници у Пољској, Југославији и Бугарској успели су, нарочито у другој половини тридесетих, да произведу неколико успешних и интересантних филмова са националнопропагандном тематиком. Можемо закључити да се, без обзира на мали број филмова, њихов утицај не може потценити јер су нудили више од штампе и радија својом комбинацијом слике и тона, што је за оно време, имајући у виду општи ниво образовања становништва, било веома упечатљиво и импресивно. 